Cell Research (2003); 13(3):179-185

http://www.cell-research.com

\title{
Delay of ZGA initiation occurred in 2-cell blocked mouse embryos
}

\author{
JiA Jing QIU ${ }^{1, *}$, Wu Wen ZHANG ${ }^{2, *}$, Zhi Li WU, Yi Hong WANG, Min QIAN², Yi Ping LI** \\ ${ }^{1}$ Institute of Biochemistry and Cell Biology, Shanghai Institutes for Biological Sciences, Chinese Academy of \\ Sciences, 200031 Shanghai, China \\ ${ }^{2}$ School of Life Science, East China Normal University, 200062 Shanghai, China
}

\begin{abstract}
One-cell mouse embryos from KM strain and B6C3F1 strain were cultured in M16 medium, in which 2cell block generally occurs. Embryos of KM strain exhibited 2-cell block, whereas B6C3F1 embryos, which are regarded as a nonblocking strain, proceeded to the 4-cell stage in our culture condition. It is often assumed that the block of early development is due to the failure of zygotic gene activation (ZGA) in cultured embryos. In this study we examined protein synthesis patterns by two-dimensional gel electrophoresis of $\left[{ }^{35} \mathrm{~S}\right]$ methionine radiolabeled 2-cell embryos. Embryos from the blocking strain and the nonblocking strain were compared in their development both in vitro and in vivo. The detection of TRC expression, a marker of ZGA, at $42 \mathrm{~h}$ post hCG in KM embryos developed in vitro suggested that ZGA was also initiated even in the 2-cell arrested embryos. Nevertheless, a significant delay of ZGA was observed in KM strain as compared with normally developed B6C3F1 embryos. At the very beginning of major ZGA as early as $36 \mathrm{~h}$ post hCG, TRC has already been expressed in B6C3F1 embryos developed in vitro and KM embryos developed in vivo. But for 2-cell blocked KM embryos, TRC was still not detectable even at $38 \mathrm{~h}$ post hCG. These evidences suggest that 2-cell-blocked embryos do initiate ZGA, and that 2-cell block phenomenon is due not to the disability in initiating ZGA, but to a delay of ZGA.
\end{abstract}

Key words: mouse embryo, two-cell block, zygotic gene activation (ZGA).

\section{INTRODUCTION}

During mouse development, the formation of a 2cell embryo marks the transition from maternal to zygotic gene dependence[1-3], a phenomenon characteristic of most, if not all, metazoa[4]. Before maturation, oocytes are transcriptionally active[5]. Transcription stops when oocytes undergo meiosis to form eggs. Oocyte maturation initiates the degradation of maternal mRNA, and this destruction is essentially complete by the end of the 2 -cell stage.

\footnotetext{
* Correspondence: Prof.Yi Ping LI,Institute of Biochemistry and Cell Biology, Shanghai Institutes for Biological Sciences, Chinese Academy of Sciences, 200031 Shanghai, China Tel: 008621-54921415 E-mail: oocyte@sunm.shcnc.ac.cn

Received Sep-3-2002 Revised May-10-2003 Accepted May-122003
}

Following fertilization the early embryo is essentially transcriptionally silent and the early development is directed by the complement of maternally inherited mRNAs and proteins. The onset of zygotic gene activation (ZGA), which is a time dependent event delayed for about $24 \mathrm{~h}$, does not occur until the 1cell embryo undergoes cleavage to form a 2-cell embryo. The maternal to embryonic transition then occurs, in which further development is directed by the zygotic transcripts. Thus, ZGA is absolutely essential for continued development[6].

Transcription of TRC (transcription requiring complex) gene(s) constitutes one of the earliest indicators of ZGA during the 2-cell stage. It is a family of three related proteins of $\sim 70 \mathrm{kD}$. Each of these proteins is heterogeneous with respect to $\mathrm{pI}(6.2 \sim$ 
6.8), nuclear-association, and insolubility in $2 \%$ Triton $\mathrm{X}-100 / 0.3 \mathrm{M} \mathrm{KCl}$. The synthesis of these proteins, which can constitute $5-10 \%$ of total protein synthesis in the 2-cell stage, is restricted to the 2-cell stage and is a-amanitin-sensitive[7].

When cultured in vitro, most mammalian embryos cannot accomplish their preimplantation development[8]. In mice, with the exception of some inbred and F1 hybrid strains, 1-cell embryos undergo a single cleavage division in vitro and are arrested at 2-cell stage, which has been termed a " 2 cell block" . On the other hand, the culture of 2-cell embryos to the blastocyst stage can be performed easily[9-11]. Reciprocal crosses between blocking and nonblocking strains indicated that this in vitro 2 -cell block is a maternally regulated occurrence [12]. The block can be rescued by the transfer of cytoplasm of embryos from nonblocking strain. This indicated that the block is mediated by a cytoplasmic component, which may be lacking in embryos from blocking strains[13]. The ability of 1-cell mouse embryos to develop in vitro has been shown to be a function of mouse strain, medium components, and culture conditions[10].

In the past decades intensive efforts have been made to elucidate the cause of 2-cell block. However there is still little information on the mechanism of this event. It has often been assumed that the block of early development is due to the failure of zygotic gene activation (ZGA) in cultured embryos. This assumption was based on the finding that both the start of the appreciable expression of the zygotic genome and the developmental arrest occurs at 2-cell stage. If the transcription is blocked in the embryos from the nonblocking strain by a-amanitin, the arrest occurs at G2 phase in 2cell stage[11]. Although the temporal coherence of the initial phase of ZGA with the critical period of 2-cell arrest is not likely to be explained just as coincidence, confirmation is still required. We therefore, in this study, compared protein synthesis patterns of 2-cell stage embryos of blocking strain and nonblocking strain mice developed either in vitro or in vivo by two-dimensional isoelectric focusing/SDS-polyacrylamide gel electrophoresis (2-D IEF/SDS-PAGE). Data demonstrated at this point indicated that ZGA was also initiated even in 2-cell arrested embryos, but ZGA was delayed for some reason in 2-cell blocked embryo as compared with those that were developed normally.

\section{MATERIALS AND METHODS}

\section{Embryo collection and culture}

Female KM and B6C3F1 mice, 5-6 weeks of age, were used to obtain the blocked and unblocked embryos at the 2-cell stage respectively. KM mice were obtained from Shanghai Experimental Animal Center, Shanghai Institutes for Biological Sciences, Chinese Academy of Sciences, Shanghai, China. B6C3F1 mice were $\mathrm{F} 1$ hybrids of C57BL/6J females and C3H males which are both non-blocking strains[11, 14], purchased from the Jackson Laboratory, Bar Harbor, Maine, USA and raised in the animal facility of Institute of Biochemistry and Cell Biology, Shanghai Institutes for Biological Sciences, Chinese Academy of Sciences, Shanghai, China.

One-cell embryos were collected from the oviducts of superovulated $\mathrm{KM}$ females mated with male $\mathrm{KM}$ mice or from $\mathrm{B} 6 \mathrm{C} 3 \mathrm{~F} 1$ females mated with male B6C3F1 mice $21 \mathrm{~h}$ following hCG injection as previously described[15]. The collection medium was bicarbonate free minimal essential medium (Earle's salts) supplemented with pyruvate $(100 \mu \mathrm{g} / \mathrm{ml})$, polyvinylpyrrolidone $(3 \mu \mathrm{g} /$ $\mathrm{ml}$ ), and $25 \mathrm{mM}$ HEPES, pH 7.2 (MEM/PVP). Cumulus cell were removed with $100 \mathrm{IU} / \mathrm{ml}$ hyaluronidase (Sigma) in MEM/PVP. Following four washes through $200 \mu \mathrm{l}$ drops of MEM/PVP and 2 additional drops of M16 medium, the embryos were cultured until the indicated stage in M16 medium with or without $24 \mu \mathrm{g} / \mathrm{ml} \mathrm{a-}$ amanitin (Sigma) at $37^{\circ} \mathrm{C}$ in a humidified atmosphere of $5 \% \mathrm{CO}_{2}$ in air[16].

\section{${ }^{35}$ S $]$ Methionine radiolabeling of embryos}

Typically groups of 50-100 embryos were radiolabeled for $2 \mathrm{~h}$ at $37^{\circ} \mathrm{C}$ in $50 \mathrm{ml}$ microdrops of M16 medium supplemented with $1 \mathrm{mCi} /$ $\mathrm{ml}\left[{ }^{35} \mathrm{~S}\right]$ Methionine (specific activity $>1,100 \mathrm{Ci} / \mathrm{mM}$; Amersham), overlaid with medium-washed paraffin oil (Sigma). Based on a $20 \mathrm{~h}$ cell cycle for one-cell embryo, embryos at the initial phase of ZGA were radiolabeled $36 \mathrm{~h}$ or $38 \mathrm{~h}$ post hCG. Mid-2-cell-stage embryos were radiolabeled $42 \mathrm{~h}$ post hCG. At the end of the radiolabeling period, only healthy looking embryos that had developed properly were washed free of extracellular $\left[{ }^{35} \mathrm{~S}\right]$ Methionine through six 200 $\mathrm{ml}$ drops of PBS/PVP, embryos were transferred into $0.5 \mu \mathrm{l}$ Eppendorf tubes, centrifuged and stored with a minimum amount of medium in $0.5 \mathrm{ml}$ Eppendorf tubes at $-70^{\circ} \mathrm{C}$.

The radiolabeled embryos were then either lysed directly or extracted first in a solution of $50 \mathrm{mM}$ Tris- $\mathrm{HCl}$ (pH 7.4), $2 \%$ Triton $\mathrm{X}-100$, and $0.3 \mathrm{M} \mathrm{KCl}$ for $10 \mathrm{~min}$ at room temperature. The TRC remained insoluble under these conditions, whereas most of the radiolabeled proteins became soluble. The zona pellucidas that retained the insoluble proteins (zona pellucida ghosts) were then washed in $50 \mathrm{mM}$ Tris- $\mathrm{HCl}, \mathrm{pH} 7.4$, and the insoluble proteins associated with them were then analyzed by gel electrophoresis[7].

\section{2-dimensional gel electrophoresis}

Radio labeled samples, prepared as above, were dissolved in 
O'Farrell lysis buffer[17] and that of $\times 10^{5}$ c.p.m. were applied to the gel. Two-dimensional isoelectric focusing/SDS-polyacrylamide gel electrophoresis (2-D IEF/SDS-PAGE) was carried out over a $\mathrm{pH}$ range of 4.5 to 7 (with ampholytes of $1.6 \% \mathrm{pH} 5-7,0.4 \% \mathrm{pH} 3-$ 10 ) on $4 \%$ polyacrylaminde tube gels for the first dimension and on $12 \%$ polyacrylaminde slab gels for the second-dimensional separation. Mini-Protean II Cell (Bio-Rad) was used according to the manufacturer's instruction manual. Bio-Rad's 2-D SDS-PAGE Standards were added to determine pIs and molecular weights of sample proteins or served as a marker for 2-D gel matching. The resulting gels were fixed, dried and exposed to Fuji X-ray film between 4-6 weeks at $-70^{\circ} \mathrm{C}$. The $2-\mathrm{D}$ gel electrophoresis for each individual sample was repeated at least three times.

\section{RESULTS}

$\mathrm{KM}$ is regarded as one of the mouse strains sensitive to the 2-cell block[18], whereas B6C3F1 is well known as a nonblocking strain[11]. To confirm this in our culture condition, we tested the rates of development beyond 2-cell stage. Fertilized eggs of two strains were cultured in a widely used and chemically defined media M16, in which 2-cell block usually occurs[19]. As shown in Tab 1, nearly all the embryos from both $\mathrm{B} 6 \mathrm{C} 3 \mathrm{~F} 1$ and $\mathrm{KM}$ developed to the 2-cell stage. About 80\% of embryos from B6C3F1 further developed to the 4-cell stage. In contrast, only $6 \%$ of embryos from KM reached the 4-cell stage, as most of them were blocked at the 2-cell stage. Thus, we confirmed the definitely different abilities between the two strains to overcome twocell block in the same culture condition.

Tab 1. Development beyond the two-cell stage of embrvos from different mouse strains

\begin{tabular}{lccc}
\hline \multirow{2}{*}{ Embryos } & $\begin{array}{c}\text { No. of 1-cell } \\
\text { embryos } \\
\text { cultured }\end{array}$ & \multicolumn{2}{c}{$\begin{array}{c}\text { No. (\%) of embryos } \\
\text { developed to: }\end{array}$} \\
\cline { 2 - 4 } & 120 & 109 & 2-cell \\
\hline KM & 159 & 27 & $126(6)$ \\
B6C3F1 & & -cell \\
\hline
\end{tabular}

The $70 \mathrm{kD}$ TRC complex has been generally used as a sensitive marker of zygotic transcription activation due to its stage specificity and high level of synthesis. The protein is encoded by an mRNA that is specifically transcribed at the two-cell stage. In this study, we also used TRC as a sign of ZGA to examine the transcription ability of embryos in the early stages.

Embryos were radiolabeled from $42 \mathrm{~h}$ to $44 \mathrm{~h}$ post-hCG, corresponding to mid-two-cell stage, at which point the synthesis of the TRC is maximal[20]. After that, samples were subjected to two-dimensional gel electrophoresis. Surprisingly, a group of

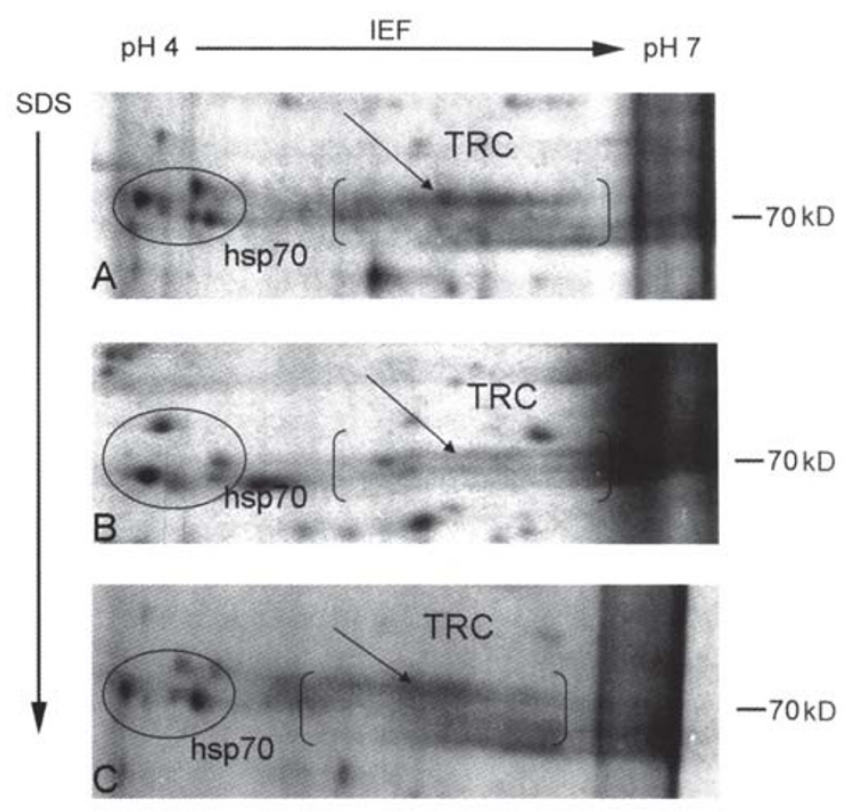

Fig 1. Two-dimensional gel analysis of the incorporation of $\left[{ }^{35} \mathrm{~S}\right]$ Methionine into embryos

(A) 2 -cell $\mathrm{KM}$ embryos in vitro, $42 \mathrm{~h}$ post $\mathrm{hCG}$.

(B) 2-cell KM embryos in vivo, $42 \mathrm{~h}$ post hCG.

(C) 2-cell B6C3F1 embryos in vitro, $42 \mathrm{~h}$ post $\mathrm{hCG}$.

Arrow: TRC, circle: hsp70.

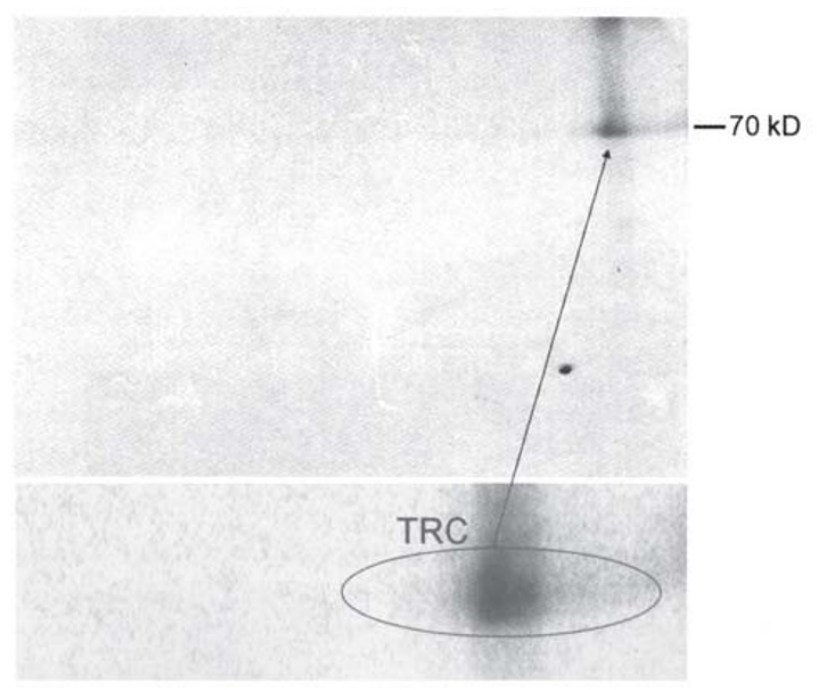

Fig 2. Two-dimensional gel analysis of the incorporation of $\left[{ }^{35} \mathrm{~S}\right]$ Methioinine into B6C3F1 2-cell embryos extracted with $2 \%$ Triton X-100/0.3 M KCl. Nearly all of the soluble proteins disappeared from the gel, but the insoluble TRC retained. 
three $\sim 70 \mathrm{kD}$ proteins with $\mathrm{pI} 6.2-6.8$, referred as TRC, were strongly detected in 2-cell blocked KM embryos, as well as that developed in vivo and the nonblocking B6C3F1 embryos developed in vitro (Fig 1).

To confirm that the TRC like complex identified on the gel is really TRC, we examined its solubility property. TRC was reported to be nuclear-associated proteins and exhibited similar properties to those of nuclear lamins with low solubility in a solution of $2 \%$ Triton $\mathrm{X}-100 / 0.3 \mathrm{M} \mathrm{KCl}$. The radiolabeled embryos were extracted first in the solution of
$2 \%$ Triton $\mathrm{X}-100 / 0.3 \mathrm{M} \mathrm{KCl}$ before applying to the gel. Most proteins were desolved away, but TRC remained insoluble following the extraction. As expected, the consequent gel was nearly blank, except a cluster of three proteins of $70 \mathrm{kD}$ with pI 6 . $2 \sim 6.8$ (Fig 2 ). The exact molecular weight, pI, and solubility properties proved it to be TRC. Since the appearance of TRC marks the initiation of ZGA, the detection of it even in 2-cell blocked embryo appeared to be in disagreement with the previous consideration that the arrest of development at two-cell stage was due to an inability to undergo ZGA.
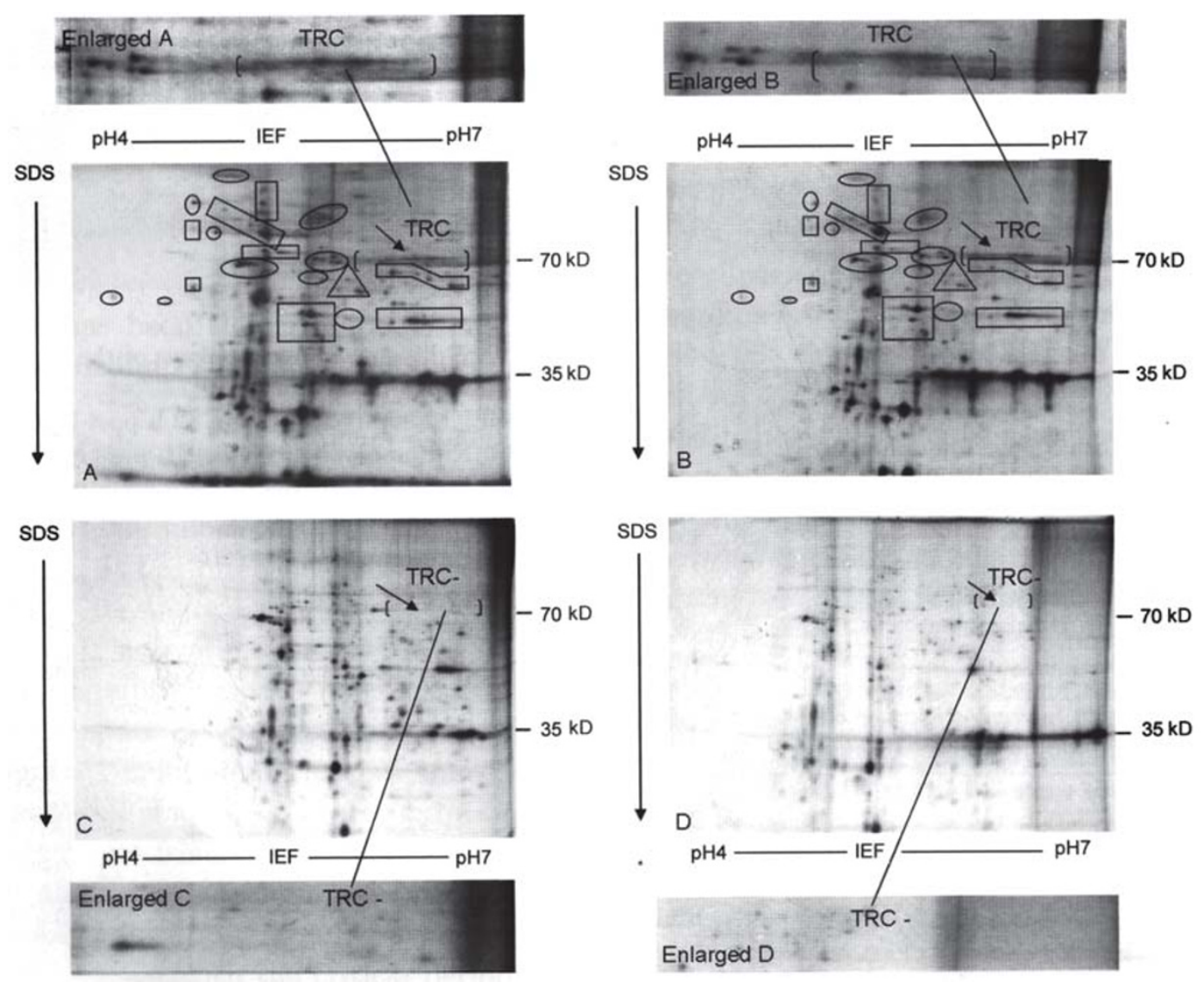

Fig 3. Two-dimensional gel analysis of the incorporation of $\left[{ }^{35} \mathrm{~S}\right]$ Methionine into embryos

(A) 2-cell KM embryo of $42 \mathrm{~h}$ post hCG developed in vitro.

(B) 2-cell B6C3F1 embryo of $42 \mathrm{~h}$ post hCG developed in vitro.

(C) 1-cell KM embryo of $27 \mathrm{~h}$ post hCG developed in vivo.

(D) 2-cell B6C3F1 embryo of $42 \mathrm{~h}$ post hCG developed with a-amanitin.

Spots or clusters of proteins encircled in (A) and (B) showed great similarity with each other, but when compared with (A) and (C), many different spots or clusters were found.

The rectangles on the top of $(\mathbf{A})$ and $(\mathbf{B})$, and those below $(\mathbf{C})$ and $(\mathbf{D})$ were their replicative enlarged view of proteins around $70 \mathrm{~K}$ TRC complex. 


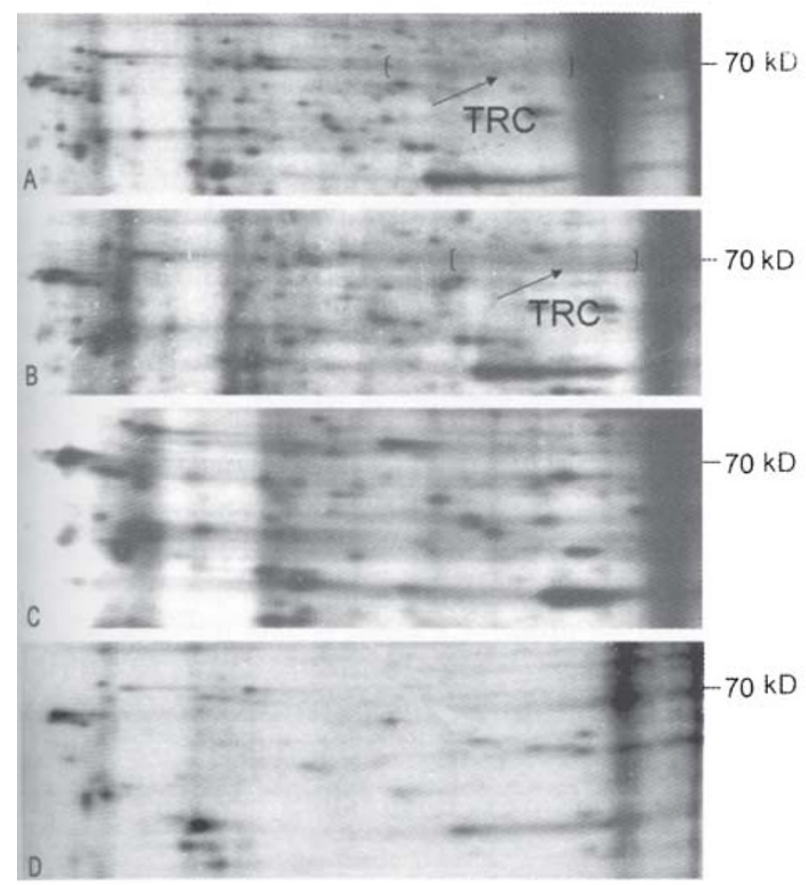

Fig 4. Two-dimensional gel analysis of the incorporation of $\left[{ }^{35} \mathrm{~S}\right]$ Methionine into 2-cell embryos at $36 \mathrm{~h}$ post hCG.

(A) KM 2-cell embryo $36 \mathrm{~h}$ post hCG developed in vivo.

(B) B6C3F1 2-cell embryo $36 \mathrm{~h}$ post hCG developed in vitro.

(C) KM 2-cell embryo $36 \mathrm{~h}$ post hCG developed in vitro.

(D) $\mathrm{KM} 2$-cell embryo $38 \mathrm{~h}$ post hCG developed in vitro.

At the period as early as $36 \mathrm{~h}$ or $38 \mathrm{~h}$ post hCG, TRC was clearly observed in 2-cell embryos from KM developed in vivo and $\mathrm{B} 6 \mathrm{C} 3 \mathrm{~F} 1$ embryos developed in vitro. But for $\mathrm{KM}$ developed in vitro, no TRC complex was detectable at this early stage.

Onset of ZGA is a time dependent event that does not begin until $24 \mathrm{~h}$ after fertilization, approximately $36 \mathrm{~h}$ post-hCG on the basis of fertilization occurred at about $12 \mathrm{~h}$ post-hCG. We then examined the expression of TRC at $36 \mathrm{~h}$ or $38 \mathrm{~h}$ post-hCG, the time equal to or shortly after ZGA initiation in the normal condition. The results showed that both B6C3F1 embryos cultured in vitro (Fig 4B) and $\mathrm{KM}$ embryos developed in vivo (Fig 4A) expressed TRC and other zygotic proteins on time. While in the case of $\mathrm{KM}$ embryo developed in vitro, however, TRC was barely detectable at either $36 \mathrm{~h}$ post hCG or $38 \mathrm{~h}$ post hCG (Fig 4). These results taken together with the above suggest that the initiation of ZGA was delayed some hours in 2-cell blocked embryos, though not absolutely disabled.

Additionally, the potent inhibiter of RNA polymerase, $\alpha$-amanitin was used to distinguish zygotically encoded transcripts from maternally encoded ones. The expression of TRC, which is one of the main products of ZGA, is absent as reported in the case that ZGA was inhibited by $24 \mathrm{mg} / \mathrm{ml}$ aamanitin. Particular dots or clusters on the 2-D gel that were absent in the a-amanitin treated embryos but present in the intact ones were identified as zygotic proteins. Our results demonstrated that other zygotic proteins besides TRC were also expressed in the 2-cell blocked KM embryos. The 2-D patterns of blocked embryos showed great similarity with those of the non-blocked embryo (Fig 3, compare A and B), while comparing with those of the 1cell stage embryos many different spots or clusters were identified (Fig 3, A and C). Therefore, it can be concluded that even embryos blocked at the 2cell stage underwent ZGA. Such an observation raises a further question about whether ZGA initiates on time in blocking strain embryos cultured in vitro.

\section{DISCUSSION}

The data presented here contradict with a previous report, in which the authors concluded that a suppression of initiation of ZGA is involved in the 2-cell block. This was proposed by the authors as an explanation of a decrease in mRNA levels observed corresponding to the critical period for 2-cell block induced by phosphate exposure at the time of ZGA [21]. Our finding of this work, which strongly suggested that ZGA do initiate even in 2-cell arrested embryo, however, minimize the likelihood of the above proposal.

Effect of different culture media on protein synthesis was examined in an earlier study[15]. An enhanced rate of total protein synthesis and higher level of synthesis of proteins were observed in embryos cultured in CZB medium, which supports the developments beyond 2-cell stage also for blocking strain embryos. It was also reported in that paper that protein synthesis is markedly retarded in embryos cultured in Whitten' s medium without EDTA that arrest the embryos at two-cell stage. This finding is in parallel with the results obtained in our study that aimed at the comparison of two different strains of embryo with different ability to progress beyond 2-cell stage in the same M16 medium. It's probably not only the retardation of the rate of total 
protein synthesis as mentioned by those authors, but also a delay in transcription as evidenced by the mRNA decrease observed in 2-cell block embryos [21] that may account together for the inability of the second round of embryonic cleavage.

Zygotic genome expression is governed by a time dependent "zygotic clock" of unknown mechanism that delays the onset of transcription for about $24 \mathrm{~h}$ postfertilization (i.e. post-hCG $36 \mathrm{~h}$ ), regardless of whether the 1-cell embryo has completed DNA replication or undergone mitosis. Acquisition of a transcriptionally permissive state occurs during the late 1-cell stage of mouse embryogenesis, but the major transcription-dependent expression begins after the formation of a 2-cell embryo[22-24]. This delay in zygotic gene expression provides a window of opportunity for remodeling parental chromosomes without accidentally and prematurely expressing their genes[25, 26]. The timing of ZGA follows the rule "go when ready". Changes in chromatin structure may underlie the timing and basis for ZGA[6]. And post-translational modification of maternally derived transcription factors is also likely involved in this time dependent event[27]. Recently, a 2-cell-stagespecific increase in polyribosomal abundance of maternal mRNA encoding some transcription factors (TFs) was observed. It was hypothesized that the regulated recruitment of maternal TFs mRNA may control the time of ZGA by controlling the time of appearance of certain TFs[28]. From this point of view, we can suppose that 2-cell block must involve delayed expression or activation of one or more transacting factors required for transcription or translation, or both of those genes that will trigger the zygotic clock[4]. Additionally, the DNA-binding activity of a number of transcription factors depends on the cellular redox potential; the oxidized forms lose their DNA-binding activity. Oxidative stress during embryo culture can thus detrimentally affect development[29]. Therefore, intrinsic causes, arising within the embryo, or extrinsic causes, present in the environment provided by the medium[16], could interfere with the precise and complicated regulation of zygotic clock, the slowing down of which may thus lead to a delay in triggering of ZGA. Autocrine diffusible factors have been reported to be necessary during 2-cell-stage for subsequent survival and normal development to the blastocyst stage
[30]. Thus, one of the possible explanations of 2-cell block would be that the delay of ZGA sequentially leads to a retardance or deficiency in producing autocrine growth/survival factors that generally initiated at late 2-cell-stage.

In conclusion, protein synthesis patterns by twodimensional gel electrophoresis of [35S] Methionine radiolabeled 2-cell embryos were examined, comparing blocking strain with nonblocking strain embryos either developed in vitro or in vivo. Our results suggest that it is not the disability in initiating ZGA but the delay of the initiation that is involved in the 2-cell block of mouse embryos in vitro.

\section{ACKNOWLEDGMENTS}

This work was supported by grants from Shanghai Scientific Development Foundation (No. 01JC14047) and National Key Basic Research Project "973" (No. G199905592).

\section{REFERENCES}

1. Cristians E, Campion E, Thompson EM, Renard JP. Expression of the HSP70.1gene, a landmark of early zygotic activity in the mouse embryo, is restricted to the first burst of transcription. Development 1995; 121:113-22.

2. Nothias JY, Majumder S, Kaneko KJ, DePamphilis ML. Regulation of gene expression at the beginning of mammalian development. J Biol Chem 1995; 270:22077-80.

3. Schultz RM. Regulation of zygotic gene activation in the mouse. BioEssays 1993; 8:531-8.

4. Kaneko KJ, DePamphilis ML. Regulation of gene expression at the beginning of mammalian development and the TEAD family of transcription factors. Dev Genet 1998; 22:43-55.

5. Wassarman PM, Letourneau GE. RNA synthesis in fullygrown mouse oocytes. Nature 1976; 261:73-4.

6. Schultz RM, Worrad DM. Role of chromatin structure in zygotic gene activation in the mammalian embryo. Semin Cell Biol 1995; 6:201-8.

7. Conover JC, Gretchen LT, Zimmermann JW, Burke B, Schultz RM. Stage-specific expression of a family of proteins that are major products of zygotic gene activation in the mouse embryo. Dev Biol 1991; 144:392-404.

8. Pang Yong, Zheng GU, Jin Ping Luo, Jun Ru WANG, Jia Ke TSO. Antibodies against the C-terminal peptide of rabbit oviduction inhibit mouse early embryo development to pass 2-cell stage. Cell Research 2002; 12(1):69-78.

9. Whitten WK, Biggers JD. Complete development in vitro of the preimplantation stages of the mouse in a simple chemically defined medium. J Reprod Fert 1968; 17:399401.

10. Chatot CL, Ziomek CA, Bavister BD, Lewis JL, Torres I. An improved culture medium supports development of random-bred 1-cell mouse embryos in vitro. J Reprod Fert 1989; 86:679-88. 
11. Aoki F, Choi T, Mori M, Yamashita M, Nagahama Y, Kohmoto KA. Deficiency in the mechanism for p34cdc2 protein kinase activation in mouse embryos arrested at 2-cell stage. Dev Biol 1992; 154:66-72.

12. Goddard MJ, Pratt HPM. Control of events during early cleavage of the mouse embryo: an analysis of the ? -cell block? J Embryol Exp Morph 1983; 73:111-33.

13. Muggleton-Harris A, Whittingham DG and Wilson L. Cytoplasmic control of preimplantation development in vitro in the mouse. Nature Lond 1982; 229:460-2.

14. Kobayashi M, Hirako M, Minato Y, Sasaki K, Horiuchi R, Domeki I. Rat hepatoma reuber $\mathrm{H}-35$ cells produces a 2cell stage-specific inhibitor of the cieavage of the mouse. Biol Reprod 1996; 54(2):364-70.

15. Poueymirou WT, Conover JC, Schultz RM. Regulation of mouse preimplantation development: differential effects of CZB medium and Whitten担 Medium on rates and patterns of protein synthesis in 2-cell embryos. Biol Reprod 1989; 41:317-22.

16. Rambhatla L, Latham KE. Strain-specific progression of a-amanitin-treated mouse embryos beyond the two-cell stage. Mol Reprod Dev 1995; 41:16-19.

17. O扚arrell, PZ, Coodman, HM, O扚arrell PH. High resolution two-dimensional electrophoresis of basic as well as acidic proteins. Cell 1977; 12:1133-42.

18. Pang Ye Fei, Xu Ri Gan. Study of fertilization in vitro and development in KM mouse ovum. The Chinese Journal of Cell Biology. 1990; 12(4):175-80. (in Chinese)

19. Biggers JD. Reflections on the culture of the preimplantation embryo. Int J Dev Biol 1998; 42:879-84.

20. Latham KE, Garrels JI, Chang C, Solter D. Quantitative analysis of protein synthesis in mouse embryos. I. Extensive reprogramming at the one-and two-cell stages. Development 1991; 112:921-32.

21. Haraguchi S, Naito K, Sato E. Phosphate exposure during the late 1 -cell and early 2 -cell stages induces a time-spe- cific decrease in cyclin B and cdc25B mRNAs in AKR/N mouse embryos in vitro. Zygote 1999; 7:87-93.

22. Majumder S, Depamphilis ML. Requirements for DNA transcription and replication at the beginning of mouse development. J Cell Biochem 1994; 55:59-68.

23. Wiekowski M, Miranda M, and Depamphilis ML. Requirements for promoter activity in mouse oocytes and embryos distinguish paternal pronuclei from maternal and zygotic nuclei. Dev Biol 1993; 159:366-78.

24. DePamphilis ML, Kaneko KJ. Regulation of gene expression at the beginning of mammalian development and the TEAD family of transcription factors. Dev Genet 1998; 22:43-55.

25. Wiekowski M, Miranda M, Nothias JY, DePamphilis ML. Changes in histone synthesis and modification at the beginning of mouse development correlate with the establishment of chromatin mediated repression of transcription. J Cell Sci 1997; 110:1147-58.

26. Henery CC, Miranda M, Wiekowski M, Wilmut I, De Pamphilis ML. Repression of gene expression at the beginning of mouse development. Dev Biol 1995; 169:44860.

27. Latham KE, Solter D, Schultz RM. Acquisition of transcriptionally permissive state during the 1-cell stage of mouse embryogenesis. Dev Biol 1992; 149:457-62.

28. Wang Q, Latham KE. Translation of maternal messenger ribonucleic acids encoding transcription factors during genome activation in early mouse embryos. Biol Reprod 2000; 62:969-78.

29. Worrad DM, Schultz RM. Regulation of gene expression in the preimplantation mouse embryo: temporal and spatial patterns of expression of the transcription factor Sp1. Mol Reprod Dev 1997; 46:268-77.

30. O抓eill C. Autocrine mediators are required to act on the embryo by the 2-cell stage to promote normal development and survival of mouse preimplantation embyros in vitro. Biol Reprod 1998; 58:1303-9. 